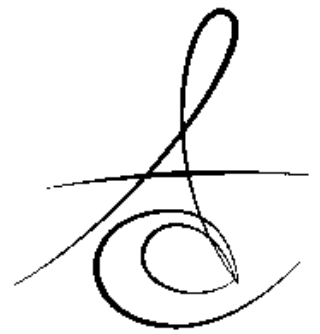

\title{
COMPARISON OF LOW VERSUS FULL BATTERY/CHARGE CONDITIONS OF ELECTRONIC APEX LOCATORS ${ }^{*}$
}

\section{ELEKTRONİK APEX BULUCU CİHAZLARIN DÜŞÜK VE TAM DOLU PİL/ŞARJ DURUMLARININ KARŞILAŞTIRILMASI ${ }^{*}$}

Yrd. Doç. Dr. Baran Can SAĞLAM*
Doç. Dr.Sibel KOÇAK*

\author{
Yrd. Doç. Dr.Ersan Çiç̧EK* \\ Doç. Dr.Mustafa Murat KOÇAK*
}

Makale Kodu/Article code: 1931

Makale Gönderilme tarihi: 21.10 .2014

Kabul Tarihi: 07.04.2014

\section{ABSTRACT}

Aim: The aim of this in vitro study was to compare the accuracy of Root ZX mini and Raypex 6 electronic apex locators (EAL) in low versus full battery/charge conditions.

Material and methods: Twenty-seven extracted human mandibular incisor teeth with mature apices were used in this study. Access cavities were prepared and all specimens were numbered. \#10 K file was introduced into the root canal until its tip was visualized at the apical foramen and the actual working length (AWL) was determined..The EALs; battery-powered Root ZX mini (J. Morita Corp, Tokyo, Japan) and rechargeble Raypex 6 (VDW, Munich, Germany) are used in accordance with the manufacturers' instructions. The electronic working length (EWL) measurement differences with Root ZX mini and Raypex 6 in low and full battery/charge conditions were compared among the groups. Statistical analyses were performed by the KruskalWallis test.

Results: No significant difference was observed between low and full charge condition of Raypex 6 groups. Although there was no significant difference between Root ZX with full battery and Raypex 6 with full charge conditions, contrary root ZX mini with low battery showed significant differences in comparison with the other groups $(p<0.05)$.

Conclusion: Although the low battery condition of the EAL may cause deviations in measurements, the accuracy of the both battery powered and charged EALs presents acceptable results in low and full battery/charge conditions within the $\pm 1 \mathrm{~mm}$ tolerance range. Nevertheless the low battery condition of the EAL may cause deviations in measurements.

Key words: electronic apex locator, Raypex 6, root ZX mini, working length

\section{ÖZET}

Amaç: Bu çalışmanın amacı Root ZX mini ve Raypex 6 elektronik apex bulucu cihazların (EAB) düşük ve tam dolu pil/şarj durumlarının kanal boyu ölçümündeki etkinliklerinin karşılaştııımasıdır.

Gereç ve Yöntem: Bu çalışmada kök ucu gelişimi tamamlanmış 27 adet daimi alt çene keser diş kullanıldı. Giriş kaviteleri hazırlandı ve tüm örnekler numaralandırıldı. 10 numara $\mathrm{K}$ tipi eğe kök kanalı içerisine ucu apikal foramende görülünceye dek yerleştirildi ve gerçek kök kanal boyu belirlendi. Pil ile çalş̧an Root ZX mini ve şarj edilebilir özellikte olan Raypex 6 EAB cihazları üretici firma talimatlarına göre kullanıldı. Elektronik çalışma boyutu tespiti ilk olarak tam dolu ardından da düşük pil/şarj seviyesine sahip Root ZX mini ve Raypex 6 cihazları ile yapıldı. Gruplar arasındaki farklılıkların kıyaslanması Kruskal-Wallis istatistiksel analizi ile yapıldı.

Bulgular: Raypex 6 ile yapılan ölçümlerde tam dolu ve düşük şarj seviyeleri arasında istatistiksel olarak anlamlı bir fark bulunmamıştır. Root ZX ve Raypex $6^{\prime}$ nın tam dolu pil/şarj seviyeleri arasında anlamlı bir fark bulunmamıştır. Düşük pil seviyesindeki Root ZX mini ile diğer deney grupları arasında ise istatistiksel olarak anlamlı bir fark ortaya çıkmışır $(p<0.05)$. Sonuç: Root ZX mini düşük pil seviyesinde farkı ölçümlere yol açmıştır ancak pil ile çalışan ve şarjı elektronik apeks bulucu cihazları ile elektronik kanal boyu ölçümünde hem düşük hem de tam dolu pil/şarj seviyelerinde $\pm 1 \mathrm{~mm}$ tolerans aralığı için kabul edilebilir ölçümler elde edilmiştir.

Anahtar Kelimeler: elektronik apek bulucu, Raypex 6 , root ZX mini, çalışma boyutu

\footnotetext{
${ }^{*}$ Bülent Ecevit University, Faculty of Dentistry, Department of Endodontics

${ }^{*}$ This study was presented as an oral presentation in "12. International Congress of Turkish Endodontic Society" (15-17 May 2014)
} 


\section{INTRODUCTION}

Determination of the working length (WL) is one of the critical factors for the success of endodontic therapy. ${ }^{1}$ Failures in WL determination such as short measurement or reading the apical foramen beyond the apex may affect the treatment success adversely. ${ }^{2}$ Therefore, clinicians must obtain accurate measurements during WL determination. The traditional radiographic method has been used to determine WL is based on the radiographic visualization of an instrument placed in the root canal for many years. ${ }^{3}$ If the apical foramen exits to the side of the root or in a buccal or lingual direction it becomes difficult to decide WL on the radiograph. ${ }^{4}$ The development of the electronic apex locator (EAL) has helped assess working length more accurately and predictably. ${ }^{4}$

It has been reported that a number of factors such as the diameter of the apical foramen, the type and size of the measuring file, the irrigation solution used or electroconductivity of the pulp may influence the accuracy of electronic apex locators. ${ }^{5,6}$ In the literature there are so many study about EAL but there is no study examined the efficacy of battery or charge status on the accuracy of the EAL.

Root ZX mini (J. Morita Corp., Kyoto, Japan) has a compact size and conveniently portable design which is a modified version EAL based on the same technology of the Root ZX. ${ }^{7}$ Besides, it offers 3 programmable memory settings, shock resistance and automatic calibration and it works with three AA batteries. $^{2}$ The Raypex 6 (VDW, Munich, Germany) is a new rechargeable multi-frequency EAL and only a few studies mentioned about this device. ${ }^{8,9}$

The aim of this in vitro study was to compare the accuracy of Root ZX mini and Raypex 6 apex locators in low versus full battery/charge conditions on the measurement of the root canal length.

\section{MATERIAL AND METHOD}

Twenty-seven extracted human mandibular incisor teeth with mature apices were used in this study. Access cavities were prepared with tungsten carbide burs and the specimens were numbered. Their actual working lengths (AWL) determined with $\# 10 \mathrm{~K}$ file were inserted into the canal until its tips was visible at the apical foramen. The distance between the tip and the stopper of the file was measured by a digital caliper with $\pm 0.01 \mathrm{~mm}$ resolution (FNCL; Worker Gage, Esteio, Brazil). All specimens and an apex locator clip were embedded in an alginate model specially developed to test apex locators.

The EALs; battery-powered Root ZX mini and rechargeable Raypex 6 were used in accordance with the manufacturers' instructions in this study. The electronic working length (EWL) measurements with Root ZX mini with full battery and a fully charged Raypex 6 were performed firstly. Measurements with the Root ZX mini were taken by advancing the file within the root canal to just beyond the foramen, as indicated by the flashing 'APEX' bar. As for Raypex 6, the file was advanced within the root canal until the third green bar limit of display was reached. All measurements were noted and were considered valid if the signal of the apex locators remained stable for at least 5 seconds. Three measurements were taken and averaged of these recorded in terms of milimeters. Low battery and low charge conditions were accepted when the battery icon was flashing on the screen for each EAL. The EWL measurements of low battery/charge conditions were performed with the same protocol.

The difference between measurements was calculated by substracting AWL from EWL for each tooth. Positive values indicated measurements that were long of the apical constriction, whereas negative values indicated measurements that were short of the apical constriction, and 0.0 values were considered coinciding measurements. Statistical analysis was performed by the Kruskal-Wallis test with SPSS 18.0 software (SPSS Inc., Chicago, IL, USA).

\section{RESULTS}

Table 1 presents the mean values of the differences between AWL and EWL in all groups. Although there was no significant difference between low and full charge condition of Raypex 6 groups and Root ZX with full battery and Raypex 6 with full charge conditions, Root ZX mini with low battery showed significant difference in comparison with the other groups $(p<0.05)$.

Both devices showed accurate results in the range of $55-85 \%$ within $\pm 0.5 \mathrm{~mm}$ and $92-100 \%$ within $\pm 1 \mathrm{~mm}$ tolerance range. Raypex 6 and Root ZX mini EALs with full battery/charge conditions showed $100 \%$ accuracy within $\pm 1 \mathrm{~mm}$ tolerance range.

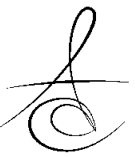


Raypex 6 EAL with low charge condition was $100 \%$ accurate and Root ZX mini with low battery condition was $92 \%$ accurate $( \pm 1 \mathrm{~mm})$. Root $Z X$ mini EAL with low battery status presents $55 \%$ accuracy within \pm 0.5 $\mathrm{mm}$ tolerance range.

Table 1 . The mean values of the differences between AWL and EWL in all groups.

\begin{tabular}{lcccccc}
\hline Group & Mean & $\mathbf{N}$ & $\begin{array}{c}\text { Std. } \\
\text { Deviation }\end{array}$ & Median Min & Max \\
\hline Raypex 6 full &,- 2648 & 27 &, 26941 &,- 3100 &,- 72 &, 27 \\
Root ZX mini full &,- 3030 & 27 &, 22240 &,- 2900 &,- 64 &, 15 \\
Raypex 6 low &,- 2841 & 27 &, 31926 &,- 2800 &,- 88 &, 36 \\
Root ZX low &,- 5407 & 27 &, 30878 &,- 5000 & $-1,54-, 07$ \\
\hline
\end{tabular}

\section{DISCUSSION}

Previous studies showed that EALs are reliable devices during working length determination in comparison with radiographic methods. ${ }^{10-12}$ Furthermore, it was suggested that reducing exposure to radiation by using apex locator may be a factor that influences a dentist's decision to choose the electronic apex locator over radiography. ${ }^{13}$ Thus, only two EALs (Raypex 6 and Root ZX mini) were compared in each other in the present study without using radiographic or another methods.

The mandibular incisor teeth with straight and single canals were selected for the present study to eliminate the anatomical handicaps during working length determination. Furthermore, the alginate model used in many previous studies were also used in this study. $1,5,12,14$

Many studies compared the various EALs to determine the superiority of each other. ${ }^{7,8,15,16}$ Moscoso et al. compared Raypex 6 and Dentaport ZX in an in vivo study and they were reported that two EALs showed similar results ${ }^{7}$ Furthermore; Raypex 6 proved to be accurate $\% 100$ of the time to $\pm 1 \mathrm{~mm}$. Similarly, Raypex 6 EAL's both low and full charge condition results also proved to be accurate $\% 100$ of the time to $\pm 1 \mathrm{~mm}$ in present study. Stoll et al. ${ }^{7}$ evaluated the effectiveness of the Root ZX mini and other three EALs to determine distance from the apical foramen and the results of the study showed that Root ZX mini had the best agreement between true lengths and meter readings.

In this study, the third green bar limit of the Raypex 6 display was considered to represent the apical constriction in accordance with a previous study that used this reference to detect the apical constriction with the Raypex 5 EAL. ${ }^{17}$ However, the choice of another display reference could alter the accuracy percentages of the electronic device. Therefore, each operator should correlate his or her own radiographic and clinical findings with the analog dial readings on the instrument. ${ }^{9}$

Taking the enormous anatomical variability of the apical region into account, some authors take 1 $\mathrm{mm}$ to be the acceptable error range. ${ }^{8,18,19}$ However, $0.5 \mathrm{~mm}$ is the margin regarded as acceptable by most authors. ${ }^{1,8,9,15}$

Raypex 6 was $100 \%$ accurate within $\pm 1 \mathrm{~mm}$ in the low and full charged conditions and these results were compatible with a previous study. ${ }^{8}$ Furthermore; $70-85 \%$ accuracy of Raypex 6 within $\pm 0,5 \mathrm{~mm}$ tolerance range was similar to the results of the recent study. ${ }^{7}$ Lucena et al. 9 reported $68 \%$ and $94 \%$ accuracy with Raypex 6 within $\pm 0,5 \mathrm{~mm}$ and $\pm 1 \mathrm{~mm}$ tolerance range. According to these finding, charge condition of Raypex 6 showed no effect on the accuracy of the EAL.

Stöber et al. reported that the Root ZX EAL was accurate $72 \%$ of the time to $\pm 0.5 \mathrm{~mm}$ and $100 \%$ of the time to $\pm 1 \mathrm{~mm} .{ }^{19}$ The similiar version of the Root ZX EAL was used in the present study and nearly the same results were obtained with full battery condition (74\%-100\%). The Root ZX mini with low battery condition results within $\pm 0.5 \mathrm{~mm}$ tolerance range were lower than the full battery mode (55\%). However, acceptable rate was achieved within $\pm 1 \mathrm{~mm}$ tolerance range in the low battery condition of Root ZX mini EAL (92\%).

Wrbas et al. compared the previous version of these two EALs (Root ZX and Raypex 5) in an in vivo study. ${ }^{20}$ They were reported that the minor foramen was located within the limits of $+/-0.5 \mathrm{~mm}$ in $75 \%$ of the cases with the Root ZX and in $80 \%$ of the cases with Raypex 5 . These results were similar except Root ZX mini with low battery condition.

Within the limitations of this in vitro study, it was concluded that the accuracy of the both battery powered and charged EALs present acceptable results in low and full battery/charge conditions with in the $\pm 1 \mathrm{~mm}$ tolerance range. Nevertheless, the low battery condition of the EAL may cause deviations in measurements. 


\section{REFERENCES}

1. D'Assunção FL, de Albuquerque DS, Salazar-Silva JR, de Queiroz Ferreira LC, Bezerra PM. The accuracy of root canal measurements using the Mini Apex Locator and Root ZX-II: an evaluation in vitro. Oral Surg Oral Med Oral Pathol Oral Radiol Endod 2007; 104:e50-3.

2. Koçak S, Koçak MM, Sağlam BC. Efficiency of 2 electronic apex locators on working length determination: A clinical study. J Conserv Dent 2013;16:229-32.

3. Duran-Sindreu F, Gomes S, Stöber E, Mercadé $M$, Jané $L$, Roig $M$. In vivo evaluation of the iPex and Root ZX electronic apex locators using various irrigants. Int Endod J 2013;46:769-74.

4. Gordon MP, Chandler NP. Electronic apex locators. Int Endod J 2004;37:425-37.

5. Herrera M, Ábalos C,Lucena C, Planas AJ, Llamas R. Critical Diameter of Apical Foramen and of File Size Using the Root ZX Apex Locator: An In Vitro Study. J Endod 2011;37:1306-9.

6. Çiçek E, Bodrumlu E. Kök Kanalında Farklı İrrigasyon Solüsyonları Varlığında Yeni Nesil Apeks Bulucu Cihazların Değerlendirilmesi Atatürk Üniv. Diş Hek. Fak. Derg. J Dent Fac Atatürk Uni 2013;21:37-42.

7. Stoll $R$, Urban-Klein $B$, Roggendorf $M J$, JablonskiMomeni A, Strauch K, Frankenberger R. Effectiveness of four electronic apex locators to determine distance from the apical foramen. Int Endod J 2010;43:808-17.

8. Moscoso S, Pineda K, Basilio J, Alvarado C, Roig M, Duran-Sindreu F. Evaluation of Dentaport ZX and Raypex 6 electronic apex locators: An in vivo study. Med Oral Patol Oral Cir Bucal 2014;19:202-5.

9. Lucena C, López JM, Martín JA, Robles V, GonzálezRodríguez MP. Accuracy of working length measurement: electronic apex locator versus conebeam computed tomography. Int Endod J 2014;47:246-56.

10. Pratten DH, McDonald NJ (1996) Comparison of radiographic and electronic working lengths. J Endod 1996;22:173-6.

11. Krajczár K, Marada G, Gyulai G, Tóth V. Comparison of radiographic and electronical working length determination on palatal and mesio-buccal root canals of extracted upper molars. Oral Surg Oral Med Oral Pathol Oral Radiol Endod 2008;106:90-3.
12. Kaufman AY, Keila S, Yoshpe M. Accuracy of a new apex locator: an in vitro study. Int Endod J 2002;35:186-92.

13. Kara TA, Gerek M. Effect of working length measurement by electronic apex locator or digital radiography on postoperative pain: a randomized clinical trial. J Endod 2014;40:38-41.

14. Tinaz AC, Alaçam T, Topuz O. A simple model to demonstrate the electronic apex locator. Int Endod J 2002;35:940-5.

15. Vasconcelos BC, Bueno Mde M, Luna-Cruz SM, Duarte MA, Fernandes CA. Accuracy of five electronic foramen locators with different operating systems: an ex vivo study. J Appl Oral Sci. 2013;21:132-7.

16. Somma F, Castagnola R, Lajolo C, Paternò Holtzman $L$, Marigo L. In vivo accuracy of three electronic root canal length measurement devices: Dentaport ZX, Raypex 5 and ProPex II. Int Endod J 2012;45:552-6.

17. Ding J, Gutmann JL, Fan B, Lu Y, Chen H. Investigation of apex locators and related morphological factors. J Endod 2010;36:1399-403.

18. Real DG, Davidowicz H, Moura-Netto C, Zenkner Cde L, Pagliarin CM, Barletta FB, de Moura AA. Accuracy of working length determination using 3 electronic apex locators and direct digital radiography. Oral Surg Oral Med Oral Pathol Oral Radiol Endod 2011;111:e44-9.

19. Stöber EK, Duran-Sindreu F, Mercadé M, Vera J, Bueno R, Roig M. An evaluation of root ZX and iPex apex locators: an in vivo study. J Endod 2011;37:608-10.

20. Wrbas KT, Ziegler AA, Altenburger MJ, Schirrmeister JF. In vivo comparison of working length determination with two electronic apex locators. Int Endod J 2007; 40:133-8.

\author{
Yazışma Adresi: \\ Yrd. Doç. Dr. Baran Can SAĞLAM \\ Bülent Ecevit Üniversitesi \\ Diş Hekimliği Fakültesi \\ Endodonti AD \\ Kozlu Zonguldak \\ e-mail: barancansaglam@gmail.com
}

